\title{
INDIVIDUAL SHAREHOLDER ACTIVISM IN SOUTH AFRICA: THE CASE OF THEO BOTHA
}

\author{
Suzette Viviers* \\ Stellenbosch University
}

Received: November 2015

Accepted: March 2016

\begin{abstract}
Shareholder activists play a key role in monitoring managerial behaviour. This study was undertaken given the paucity of research on the shareholder activism as practised by individual shareholders. Accordingly, the motives, modus operandi and sources of salience of Mr Theo Botha, a well-known shareholder activist in South Africa, were investigated. Document analysis and an in-depth interview conducted with Botha revealed that he not only has a clear goal, but is also very passionate about achieving his goal. Botha prepares meticulously before engaging companies across the economic spectrum. In addition to possessing normative power, Botha also exhibits individual, pragmatic and societal legitimacy. His assertiveness, persistence and willingness to apply his own resources significantly contribute to his prominence as a corporate watchdog. Shareholder activists who wish to become more salient (irrespective of their size) could learn from Botha's experiences over the past decade.
\end{abstract}

\section{Keywords}

Board diversity, Gender diversity, Race diversity, Accounting-based financial performance, Market-based financial performance

Shareholder activism, shareholder engagement, corporate governance, shareholder salience, normative power, individual legitimacy, individual investor, Theo Botha

*Prof S Viviers is professor in the Department of Business Management, Stellenbosch University, South Africa [sviviers@sun.ac.za]. 


\section{INTRODUCTION}

First they ignore you, then they laugh at you, then they fight you, then you win.

This quote by Mahatma Gandhi (1897-1948) aptly captures the essence of what many activists experience in their endeavours to bring about change.

Shareholder activists are investors who use their equity stake in the companies in which they invest (hereafter called investee companies) to ask questions and demand corporate accountability. Shareholder activism has long been an important mechanism to limit managers' divergence from the goal of maximising shareholders' wealth (Partnoy \& Thomas, 2005). Investors who seek to influence the nature of policies and practices of investee companies can employ different mechanisms to do so. They can engage in private discussions with management, file shareholder resolutions, ask questions and vote at annual general meetings (AGMs). They can also initiate litigation, voice their concerns in the media or divest from companies that fail to transform (Nordén \& Strand, 2011).

One of the first examples of public shareholder activism occurred in the 1960s when shareholders divested from Dow Chemical for supplying toxins such as napalm and Agent Orange to the U.S. military in Vietnam (Welker \& Wood, 2011). Shareholder activism is a growing phenomenon at present (Poulsen, Strand \& Thomsen, 2010) and is mainly practised by institutional investors across the globe (Blume \& Keim, 2012; Hadani, Goranova \& Khan, 2011; Lantz, Montandrau \& Sahut, 2010; Wen, 2009). Institutional investors, such as pension funds, invest large amounts of capital into financial instruments such as stocks, bonds, commodities and foreign exchange, either for their own gain, or on behalf of other institutions or individuals. Shareholder activists currently engage companies on a wide range of ethical as well as environmental, social and governance (ESG) risks (Chung \& Talaulicar, 2010).

Given the size and ability of institutional investors to influence corporate decisions the majority of shareholder activism research centres on these investors. As far as could be established, no research has focused exclusively on the shareholder activism endeavours of individual (retail) investors. In contrast to institutional investors, individual investors are investors who own stock in a company in their personal capacity. The paucity of research in this field is probably due to the fact that individual shareholders are not seen as salient shareholders, where salience is defined as the degree to which management gives priority to the claims of a particular shareholder (Gifford, 2010:79). Two notable exceptions include that of Carl Ichan in the US (Foley, 2014) and Theo Botha in South Africa (Bhana, 2010; Mamtse, 2007).

Theo Botha is not the only individual shareholder activist in South Africa, but he is by far the most prominent one (Barron, 2011; Hogg, 2009; Shevel, 2014). Botha was born on 1 March 1960 and obtained a Bachelor of Commerce (Honours) degree in Accounting at the University of South Africa. He completed his articles at PricewaterhouseCoopers, but returned to his family's farm in 1987 after his father passed away (Steyn, 2011). Botha is currently part-owner and director of CA Governance, a leading independent corporate governance practitioner in South Africa (CA Governance, 2014).

After making a small investment in The Sage Group, a South African life assurance company, in 2002, Botha discovered that the company failed to disclose losses in its US operations to local shareholders (Keeping tycoons on their toes, 2007). He privately questioned management on the omission only to be told that the company's financial statements complied with the legal disclosure requirements in South Africa. Unsatisfied with management's response, Botha raised 
the issue at Sage's AGM. As he received the same brush-off as earlier, he decided to approach the media. Not only did the company's share price decrease dramatically in response to the media reports, but its credit rating was also downgraded a few weeks later (Planting, 2012).

Since his initial deliberations with The Sage Group, Botha has engaged numerous companies listed on the Johannesburg and London Stock Exchanges. His efforts in highlighting unsatisfactory accounting, financial and ESG practices has earned him a reputation as a corporate watchdog a 'terrier' to be more specific (Creamer, 2009; Shevel, 2014). The so-called 'Botha sting' has been shown to result in a significant decrease in the target company's share price directly after his public criticism (Bhana, 2010).

Given that there has been limited research on individual shareholder activism, the objective of this article was threefold. In the first instance, an investigation on Botha's motives for engaging public companies was launched. This was followed by an analysis of Botha's modus operandi as an individual shareholder activist. Specific attention was given to the nature of engagements, the type of companies that came under Botha's magnifying glass and the issues raised. Thirdly, Botha's actions were evaluated in terms of the three sources of shareholder salience as postulated by Gifford (2010), namely power, legitimacy and urgency.

If shareholder activists, large or small, want to become more prominent watchdogs and change agents, they should give more attention to the manner in which they engage investee companies. Insight into what is required to be an effective shareholder activist can be gleaned from Botha's character and actions. The remainder of this article is structured as follows: key constructs associated with shareholder activism and salience will be defined next, followed by a brief overview of the methods used to collect and analyse data. Pertinent conclusions are then drawn from Botha's motives, modus operandi and sources of salience as an individual shareholder activist.

\section{SHAREHOLDER ACTIVISM}

Since shareholders are the owners of a company, they have an interest in and right to consult with management on issues which influence shareholder value. Financially motivated shareholder activists therefore typically pressure management to spin off loss-making divisions, reduce executive compensation and increase dividend pay-outs (Gillan \& Starks, 2000). Although most shareholder activism is financially oriented (Gantchev, 2013; Ntim, Opong \& Danbolt, 2012), social shareholder activism is also on the rise. Socially oriented shareholder activists endeavour to create a more just society and typically probe companies on issues relating to sustainability and human rights (Hendry, Sanderson, Barker \& Roberts, 2007; Judge, Gaur \& Muller-Kahle, 2010). In South Africa, non-financial shareholder activism has mainly focused on public companies' compliance with the King reports on corporate governance (Lekhesa, 2009; Rademeyer \& Holtzhausen, 2004).

Investors' preferences for public versus private activism depend to a large extent on the culture in a particular country. Evidence suggests that shareholder activists in the US prefer public activism (Davis \& Han Kim, 2007; Poulsen et al., 2010), whereas their counterparts in the United Kingdom (UK) prefer private activism (Cohen, 2011; Becht, Franks, Mayer \& Rossi, 2010; Winfield, 2011). Investors' preferences for specific engagement mechanisms also depend on their ability to access management. Access has been shown to be all but impossible for individual investors. They are therefore forced to use public forms of shareholder activism, such as asking probing questions 
at AGMs. Research shows that the presence of individual shareholder activists at AGMs is often seen as an annoyance by management. Be this as it may, the actions of these so-called 'gadflies' have, in some instances, resulted in managers revising their policies for fear of reputational damage (De Bakker \& Den Hond, 2008).

\section{SHAREHOLDER SALIENCE}

Shareholder salience can be defined as the degree to which managers give priority to the claims of a particular shareholder (Gifford, 2010). It consists of three overarching attributes, namely power, legitimacy and urgency. More details on these attributes are presented in TABLE 1 .

Power refers to the extent to which a shareholder can gain access to coercive, utilitarian or normative means to impose his or her will on the investee company. Institutional investors with significant stakes in investee companies are more likely to use coercive power (through the provision or withdrawal of capital) to bring about corporate change in investee companies (Sjöstrom, 2008). Legitimacy refers to a generalised perception or assumption that the actions of an entity or individual are desirable, proper or appropriate within some socially constructed system of norms, values, beliefs and definitions.

\section{TABLE 1: Attributes of shareholder salience}

\begin{tabular}{|c|c|c|}
\hline \multicolumn{2}{|c|}{ Attribute } & \multirow{2}{*}{ Sources of salience } \\
\hline Power & Coercive & \\
\hline & & Replacement of directors or chief executive officer (૮દ૦). \\
\hline & & Legal proceedings to enforce shareholder rights. \\
\hline & & Successful lobbying for regulation. \\
\hline & Utilitarian & $\begin{array}{l}\text { Provision or withdrawal of capital or other resources from companies } \\
\text { (investment or divestment). }\end{array}$ \\
\hline & Normative & $\begin{array}{l}\text { Public or private statements, shareholder resolutions or other } \\
\text { activities that affect the company's or individual managers' } \\
\text { reputations. }\end{array}$ \\
\hline \multirow[t]{7}{*}{ Legitimacy } & Individual & $\begin{array}{l}\text { Expertise, experience, status and credibility of the individual } \\
\text { engaging the company. }\end{array}$ \\
\hline & Organisational & $\begin{array}{l}\text { Legitimate claim on the company (e.g. large shareholding, high-risk } \\
\text { stake). }\end{array}$ \\
\hline & & $\begin{array}{l}\text { Alignment between the shareholder's interests and those of the } \\
\text { company. }\end{array}$ \\
\hline & & $\begin{array}{l}\text { Perception that the shareholder organisation is a credible and } \\
\text { respected member of the investment community. }\end{array}$ \\
\hline & & $\begin{array}{l}\text { Consistency of messaging from different parts of the shareholder } \\
\text { organisation. }\end{array}$ \\
\hline & Pragmatic & $\begin{array}{l}\text { The shareholder has a strong argument for why the proposed action is } \\
\text { in the interests of the company. }\end{array}$ \\
\hline & & The shareholder provides new information to the company. \\
\hline
\end{tabular}




\begin{tabular}{|c|c|c|}
\hline \multicolumn{2}{|c|}{ Attribute } & Sources of salience \\
\hline \multirow{9}{*}{ Urgency } & Societal & $\begin{array}{l}\text { The shareholder embodies or reflects a position widely accepted in } \\
\text { society. }\end{array}$ \\
\hline & & Existence of norms or codes of conduct. \\
\hline & & Supportive political and policy environment. \\
\hline & Time- & Shareholder resolutions at AGMs. \\
\hline & sensitivity & Benchmarks with deadlines for response. \\
\hline & & Use of other forms of deadlines to create time pressure. \\
\hline & Criticality & Assertiveness of tone. \\
\hline & & Persistence. \\
\hline & & Willingness to apply resources. \\
\hline
\end{tabular}

Source: Gifford (2010:80)

All four types of legitimacy, be it individual, organisational, pragmatic or societal, are applicable to institutional shareholders. In cases where the activist is an individual shareholder (as in Botha's case), organisational legitimacy becomes irrelevant. The third source of shareholder salience is that of urgency, and indicates the degree to which a shareholder's claims call for immediate attention from the investee company. Once again, institutional shareholders are more likely to obtain cooperation from investee companies than individual shareholders.

\section{RESEARCH DESIGN AND METHODOLOGY}

Given the exploratory nature of the study, a phenomenological research paradigm was deemed appropriate for this study (Babbie \& Mouton, 2001). The adoption of this paradigm had two further advantages. Firstly, it enabled the researcher to attach meaning to the phenomenon of individual shareholder activism rather than merely measuring it. Secondly, it gave the researcher an opportunity to interact personally with the subject. This interaction proved invaluable, as questions about personal convictions and challenges could be raised in person.

As mentioned earlier, Botha is not the only individual shareholder activist in South Africa. Over the years individuals such as Issy Goldberg, Roy McAlpine, Chris Logan and a gentleman colloquially called 'Mr Hayden' also made headlines for questioning companies listed on the Johannesburg Stock Exchange (JSE) on financial, accounting and governance irregularities (Barron, 2011; Carte 2011c; Mamtse, 2007; Mathews \& Hasenfuss 2013). Botha was, however, selected as the research subject in this study, as he is seen as the most prominent individual shareholder activist in the country (Gardee, 2014; Mpofu, 2013; Shevel, 2014).

Qualitative data was collected in two phases. In the first instance, secondary data on Botha's engagements from May 2002 to July 2014 was sourced from local newspapers, magazines and academic journal articles. An analysis of the documentary evidence was then supplemented by an in-depth personal interview with Botha in July 2013. The interview shed light on Botha's raison d'être, modus operandi as well as his views on various aspects of shareholder activism in South Africa. To address the problems of selective deposit and selective survival associated with documentary evidence (Babbie \& Mouton, 2001), follow-up discussions were held with Botha to verify the data collected. This process resulted in the addition of a number of engagements. 
The collected data was codified to determine recurrent patterns and inconsistencies. The three phases of deductive qualitative content analysis as proposed by Elo and Kyngäs (2007) were employed in this study. A structured analysis matrix was developed and used to code the secondary and primary data. The creation of categories specifically enabled the researcher to evaluate Botha's sources of salience relative to Gifford's (2010) theoretical framework.

Given the nature of the study, Botha's anonymity could not be protected. He consented to this study and had the opportunity to verify the accuracy of data contained in this article. A certain degree of subjectivity might be evident in the results, as the focus of the study was to highlight the factors that could contribute to Botha's salience as an individual shareholder activist.

\section{RESULTS AND DISCUSSION}

In the following section, reference to the interview with Botha will be indicated as (TB). Other data sources reporting on Botha's activism endeavours will be referenced by giving the relevant author's name in brackets.

\subsection{What drives Theo Botha as an individual shareholder activist?}

The data analysis revealed that Botha is driven by the aspiration to hold directors and managers accountable, to protect the interests of other (typically minority) shareholders, to stimulate public debate and to expose unwarranted agency costs. Botha is primarily motivated by his desire to keep big corporates on their toes (Steyn, 2011), particularly as it pertains to corporate transparency and accountability (Crotty, 2009b; Planting, 2012). With the phasing in of the second King report on good corporate governance (King II) in 2002, many South African companies were saying that they were adhering to King II 'as if nothing had changed from King I' (TB). Botha thus started to investigate listed companies' adherence to these guidelines. 'It became a matter of exposing directors. They say they are independent, yet some have been directors for 20 years ... they are bound to lose independence. And there's nobody to question them' (TB in Mamtse, 2007).

Unfortunately, not much has changed since the introduction of the third King report (King III) in 2009 (Barron, 2011; Hogg, 2010). 'Everybody is just saying King II and King III are good and the auditors are stamping it. But nobody is holding companies to account' (TB). As a shareholder watchdog, Botha thus ensures that those issues that companies would rather keep to themselves are publicised (Barron, 2008). Botha is widely regarded as a passionate 'crusader for good corporate governance' in South Africa (Carte, 2009; Hasenfuss, 2006), and has particularly a strong opinion about executive remuneration (Crotty, 2012a; Hogg, 2010).

At one AGM, Botha wanted to know why the company was so 'generous' towards the chairman of the remuneration committee and the chairman of the board, in the light of weak shareholder returns in the preceding year (Hogg, 2008). Botha has recently broadened his accountability focus to include matters pertaining to environmental and social risk management. His watchdog status is aptly captured in Shevel's (2014) headline: 'Terrier-like Botha keeps companies on a leash'.

Being described as the 'face of minority shareholder activism' in South Africa (Harris, 2011b; Mpofu, 2013), Botha has first-hand experience of being marginalised. Much of his engagement with South African companies has thus been undertaken to protect and promote the interests of other individual and minority shareholders (Hasenfuss, 2009b; Mchunu, 2007b; Schumacher, 2009). Botha is furthermore driven by the desire to raise public awareness on socially relevant 
issues. In the South African context, these issues typically centre on Broad-based Black Economic Empowerment (B-BBEE), HIV/AIDS and the ever-increasing wage gap (Barron, 2014; Gilmour, 2014; Sathekge, 2011; Tarrant, 2013).

His motivation for raising these concerns in the public domain is because companies simply 'pay lip service to corporate governance and nobody really cares' (Keeping tycoons on their toes, 2007). Botha is also quite critical of the high level of apathy among local shareholders, especially large institutional shareholders such as the Public Investment Corporation (Hogg, 2010; Mathews \& Hasenfuss, 2013).

Botha's contribution to the transformation debate in South Africa was acknowledged by the Black Management Forum in 2008, when they bestowed their highest leadership award on him (Radebe, 2008). In their role as social commentators, journalists often highlight his influence on corporate decision-making. Hogg (2009) even thanked Botha for challenging South African executives on the issue of remuneration - 'the more you [Botha] shine a light into dark areas, the more things can change'. A year later, the same author applauded Botha for 'pointing out these issues and raising the public's awareness of executive remuneration ... which remains a festering sore' (Hogg, 2010). As Botha does not benefit financially from his activism endeavours, the researcher is of the opinion that he sees his work as a higher calling.

\subsection{How does Botha engage companies in his capacity as an individual shareholder activist?}

Botha claims that there is no specific pattern in selecting target companies. Instead, his interest in a particular company is piqued by newspaper articles highlighting problematic corporate behaviour. In line with institutional investors (Sjöstrom, 2008), Botha also targets large, wellknown companies. These companies tend to be in the firing line, as they have significant socioeconomic and environmental footprints. Changes in corporate policies and practices in these companies are thus likely to have more substantial impacts than if the same changes occurred in smaller companies. Once a company has been selected, Botha prepares meticulously for meetings. It could take him up to five hours to examine an annual report. He reads at least five years' of annual reports before attending a company's AGM (Barron, 2008) and scrutinises circulars and information posted on the web (TB; Tredway, 2004). 'From the Sage experience in 2002 l've learnt to read through a company's public information very closely' (TB).

Careful attention to detail in annual reports has enabled Botha to uncover a number of accounting errors and inconsistencies (as with The Sage Group in 2002). In 2009, Botha exposed a gross error in calculating the emolument package of a prominent director. In commenting on the mistake, Hasenfuss (2009c) wrote: 'Did they [referring to the remuneration committee] not spot the cockup, which was apparently easily picked up by Botha? What would have happened if Botha had not raised the issue of the conspicuously inflated package?' The same journalist acknowledged that Botha is often seen as 'a pedantic nit-picker', pointing out that this character trait is valuable in exposing 'cracks in management'.

Whilst preparing for an AGM, Botha often requests the minutes of previous years' meetings. He admits that there are often hurdles to accessing company data, especially if he is not a shareholder of the particular company. Steyn (2011), however, observes that Botha is 'never fazed' by this and simply buys one share. Botha occasionally informs management that he will be attending the company's AGM and has even sends his questions beforehand 'as not to waste time at the AGM' (TB). In one exceptional case, the CEO of a large banking group contacted Botha prior 
to the AGM. As all of Botha's questions were sufficiently answered by the $C \varepsilon 0$, he did not attend the company's AGM that year. 'The following year the CEO did exactly the same' (TB). Although Botha sporadically engages management behind closed doors, he prefers to raise his concerns in public, either by asking questions at the target companies' AGMs (Shevel, 2014). As indicated earlier, individual shareholders hardly ever get access to management and are therefore limited to raising their concerns at AGMs and in the media.

The chairperson of a large South African company opened its AGM by asking if there were any questions and immediately added 'of course, Theo, it wouldn't be an AGM unless you had questions' (Rose, 2007b). Journalists have likened Botha's questioning strategy to a flood or barrage (Harris, 201la; Vanek, 2012c). Botha's strategy for asking questions at AGMs has changed over the years. Where he initially had a long list of questions, he is now much more selective in the issues which he would like management to address (TB). His questions have been described as probing, prickly, tricky, awkward, embarrassing, uncomfortable, hard-hitting and difficult (Anderson, 2006b; De Waal, 2011; Hasenfuss, 2007, 2009b; Hogg, 2010, 2011; Planting, 2012; Tarrant, 2014). Media commentators have even remarked that Botha 'grills' directors or 'turns up the heat' (Anderson, 2006b; Carte, 2011; Mantshantsha, 2006). As will be indicated later, directors and managers generally respond in a hostile manner to this kind of interrogation. As indicated in TABLE 2, Botha has attended 136 AGMs of 54 companies over the research period.

TABLE 2: Botha's main modus operandi over the period May 2002 to July $2014^{(a) \&(b)}$

\begin{tabular}{ll}
\hline Asking questions at AGMs & 136 AGMs \\
\hline Making comments about a company/manager in the media & 34 cases \\
\hline Engaging in private discussions with management prior to or after the AGM & 8 cases \\
Engaging the JSE about 'misbehaving' listed companies & 3 cases \\
Initiating legal proceedings & 2 cases \\
(a) These categories are not mutually exclusive. & \\
(b) The names of the companies and the sources used to compile this table are available from the researcher on request.
\end{tabular}

Source: Author's analysis

Perusal of TABLE 2 shows that the most AGMs that Botha attended in one year (22) occurred in 2009. The majority of his corporate governance-related engagements (75\%) occurred after the 2008 global financial crisis and highlights the role that corporate governance plays in aggravating and perpetuating crises (Mitton, 2002).

Botha has engaged South African companies across a broad economic spectrum, more specifically: cyclical services (25.4\%), resources (19.4\%), financials (16.4\%), non-cyclical consumer goods $(10.4 \%)$, basic industries $(9 \%)$, general industries $(9 \%)$, non-cyclical services (6\%), cyclical consumer goods (3\%), information technology (3\%) and utilities (1.5\%). A summary of the financial and ESG issues which Botha has raised at AGMs and in the media since 2002 is presented in TABLE 3. 


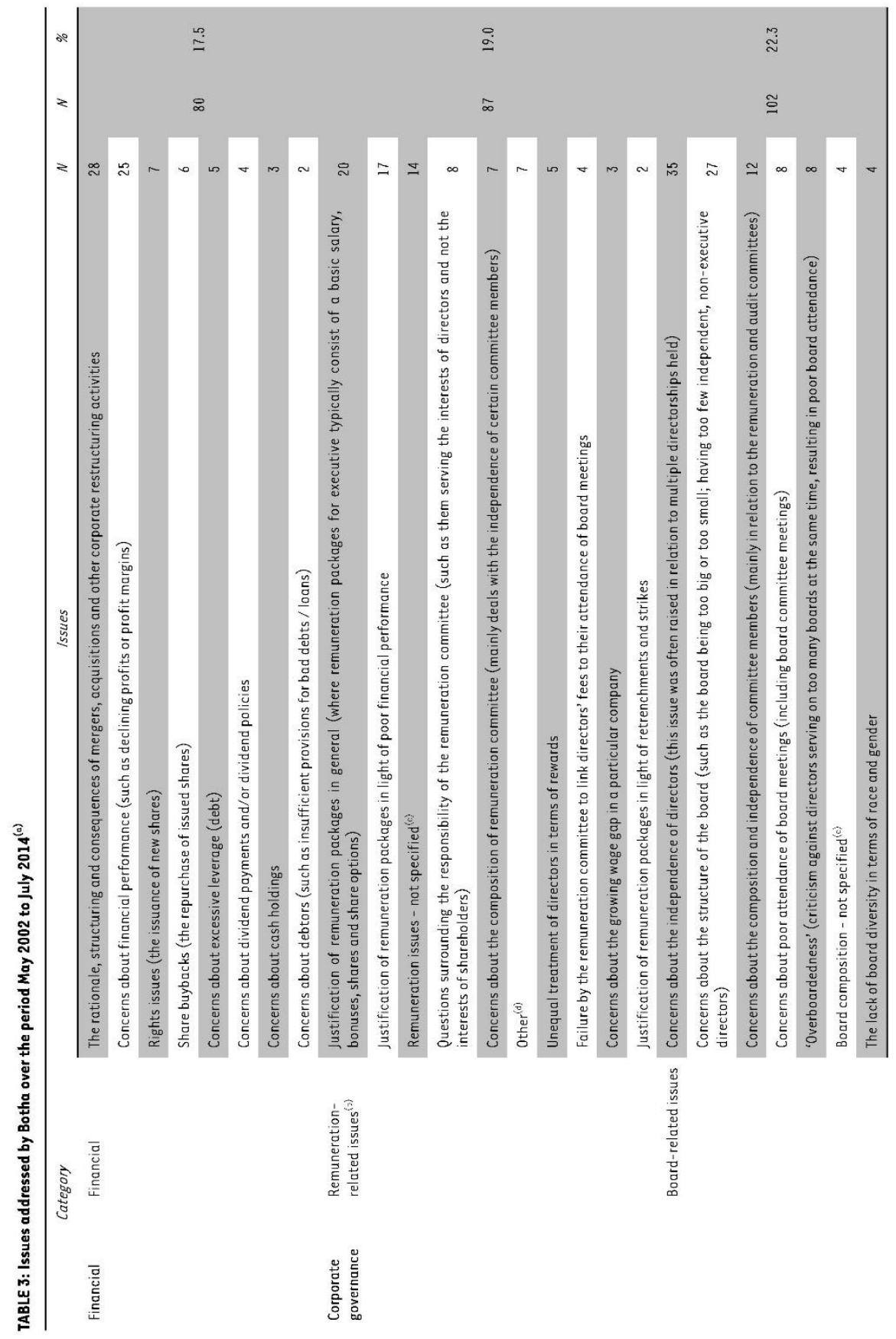




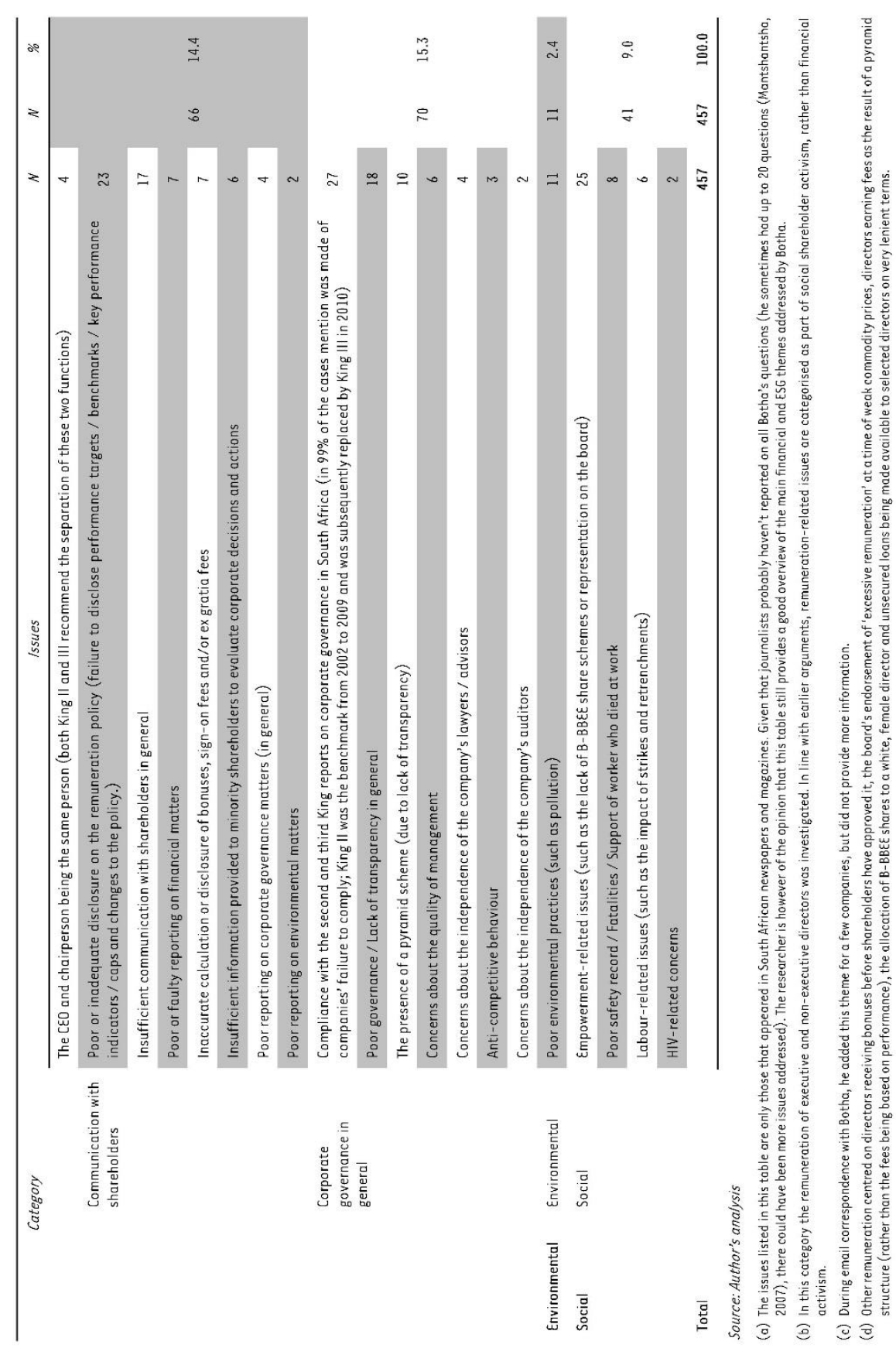


The evidence in TABLE 3 suggests that Botha is indeed a 'crusader for good corporate governance' (Hasenfuss, 2006). Botha's concerns about executive remuneration were often mentioned in the same breath as poor financial performance. In line with international trends (Barron, 2014; Patton, 2014), Botha criticised companies heavily for failing to disclose the performance targets, benchmarks and key performance indicators used to determine the level and nature of executive remuneration (Gilmour, 2014; Hedley, 2013; De Waal, 2011; Rose \& Shevel, 2009). Botha argues that more information is necessary to hold remuneration committees accountable and to determine whether executive pay is appropriate or excessive (TB in Crotty, 2012a).

Botha often highlighted companies' lack of compliance with the King reports, specifically on issues such as the lack of independent directors, poor attendance of board meetings and insufficient communication with shareholders. The researcher finds it disconcerting that so many JSE-listed companies still (in 2015) disregard many of the recommendations contained in the King reports.

Although Botha has mostly criticised companies, he has, on occasion, applauded some companies for improved reporting (Anderson, 2006a; Crotty, 2013). On a question of whether he ever becomes nervous at AGMs, Botha responded: 'Of course I'm nervous, I'm very nervous. But I don't shout, I don't scream, I just go through the questions' (TB in Barron, 2008). After meetings, Botha generally leaves pretty quickly, but he always requests that his questions and management's replies be properly recorded in the AGM's minutes (Crotty, 2011a; Petros, 2009). The need for sound recordkeeping will allow al/shareholders (not only shareholder activists) to hold managers accountable for promises they have made.

In one instance, the company secretary failed to mention any of Botha's questions or the company's responses in the minutes. As a private request for the information was unsuccessful, Botha applied for a copy of the full meeting notes using the Promotion of Access to Information Act (Planting, 2014). Unfortunately, his application was unsuccessful (TB). As a last resort, shareholder activists can pursue legal proceedings. In 2005, Botha turned to the Johannesburg High Court to prevent a large life assurance company from snapping up a smaller rival (Rose, 2005). Despite his application, the court sanctioned the transaction. Given the high cost of litigation, Botha no longer employs this mechanism to fight for the rights of minority shareholders. In a few rare cases Botha has also reported suspect corporate behaviour to the JSE (Hasenfuss, 2008; Hogg, 2009).

Like activists in other realms of life, Botha also evokes strong emotions among those he confronts (Flam \& King, 2007). Having gained some insight into the character, motives and modus operandi of Botha, the focus will now shift to an evaluation of what makes him a salient shareholder. Attention will be given to the three attributes of shareholder salience, namely power, legitimacy and urgency.

\subsection{Which sources of power does Botha pose as an individual shareholder activist?}

Shareholder activists use coercive power when they file shareholder resolutions, replace directors or CEOs or engage in legal proceedings. In contrast to the US, very few (if any) shareholders in South Africa have filed shareholder resolutions in the past two decades (Viviers \& Smit, 2015). This might be attributed to the high costs associated with doing so. From a cultural point of view, it is more acceptable for South African shareholders to engage in private negotiations with 
management (Vanek, 2012a). Despite Botha following a very public activism approach, he has never filed a shareholder resolution.

In his personal capacity as individual shareholder activist, Botha has not been able to have directors or CEOs replaced, but he has expressed very firm views about the quality of certain executives (Harris, 2014, Jones, 2014; Seccombe, 2012). As pointed out earlier, Botha has initiated legal proceedings only once before to enforce his rights as a minority shareholder (Rose, 2005). As this application was unsuccessful, Botha no longer 'quotes the law or gets involved in litigation' (TB). He deems this route to having his voice heard as too expensive.

Successfully lobbying for regulation represents a fourth source of coercive power. Long-awaited amendments to Regulation 28 of the South African Pension Funds Act (No. 24 of 1956) were promulgated in 2011 in response to sustained pressure by a few institutional investors. Although Botha was not directly involved in the lobbying process, he supports the amendments (TB).

Utilitarian power is associated with the provision or withdrawal of capital or other resources from companies (Gifford, 2010). Being an individual shareholder who often only owns one share, Botha has no utilitarian power. Instead, his prominence as a shareholder activist hinges almost entirely on the level of normative power that he has. As explained in TABLE 1 , normative power results from public or private statements that affect the reputation of the targeted company or individual. Botha himself acknowledges that he knows how to use the media to his advantage. Reflecting on his first engagement with The Sage Group, he remarked: 'I got nowhere with them [the directors], so I went to the press. They ran the story and that was the end of the company. They had destroyed their own reputation. The share price tanked' (TB in Barron, 2008). More recently, another financial institution experienced the 'Botha sting' first-hand. Botha claimed that 'management had underestimated the severity of the problem [bad loans] and did not provide adequately for loans. The company's reputation and management's reputation is tarnished' (TB in Barry, 2014a).

So strong is Botha's normative power that a multi-national mining company had to apologise to him in public for denying him access to the company's AGM. The company secretary not only apologised, but also offered to reimburse Botha's travel expenses to London and to provide answers to all the questions he intended to raise at the AGM (Ngcobo, 2011). Botha also insisted that Lonmin plc hold a minute of silence at its AGM after the Marikana shooting in 2012 (TB; Crotty, $2012 \mathrm{~b}$ ). The platinum producer's failure to show respect for the 50 employees who died in the incident damages their reputation, particularly as their mission is said to be based on 'a valuesbased culture', which includes safety at work (Our mission and values, 2016). Botha's normative power is furthermore evident in the responses he elicits at AGMs. It has been said that Botha possesses the rare ability to 'incite an instant headache' for executives when he arrives unannounced at their AGMs (Rose, 2007b). It could be argued that managers develop a headache in anticipation of the reputational damage they know Botha can cause (Bhana, 2010).

\subsection{Is Botha seen as a legitimate individual shareholder activist?}

As indicated earlier, legitimacy can be defined as generalised perceptions or assumptions that the actions of an entity or individual are desirable, proper or appropriate within a socially constructed value system. In the following section, Botha's activism endeavours will be evaluated in terms of individual, pragmatic and societal legitimacy.

Individual legitimacy can be measured in terms of the expertise, experience, status and credibility of the individual in question. The degree to which a shareholder activist is considered legitimate can be viewed from various perspectives. For the purpose of this article, two perspectives are 
deemed particularly important: perspectives from those who have been engaged by Botha in the past (such as directors, executives and company secretaries) and perspectives from social commentators (such as journalists). Views from fellow shareholders, policy-makers and the public at large could be investigated in future research.

The findings of this study suggest that both of the considered groups view Botha as an individual shareholder activist whose actions are 'desirable, proper and appropriate' within the South African investment context. His expertise, experience and status are derived from his accounting education, extensive knowledge of corporate governance codes, attentive study of annual reports and regular attendance of AGMs. Not only does Botha have an eye for detail, but he also ensures that his facts (or arrows as he calls them) are correct before he confronts managers. To strengthen his case, Botha has even requested information from the US Securities and Exchange Commission to clarify issues in the annual report of a dual-listed company before confronting the company and going public (Hasenfuss, 2010). The fact that Botha does not criticise companies and directors before verifying all the relevant facts increases his legitimacy.

Perceptions between the two groups diverge when it comes to the topic of credibility. Whereas 'chairmen often can't stand the sight of him' (Barron, 2008), journalists argue that South Africa needs more people like Botha who are 'informed and unafraid of asking powerful people uncomfortable questions' (Ngcobo, 2011). The following extracts paint a picture of how directors and managers perceive and respond to Botha's engagements; words in brackets have been inserted by the researcher:

- 'Many companies take a sour view of Botha pitching up at their shareholder meetings with a raft of questions' (Sexwale and the shy activist, 2007).

- Botha causes 'controversy everywhere he goes'. 'It didn't take long after the start of the shareholders' meeting for Botha to rattle the cage. The chairman was immediately annoyed when Botha raised his hand for a question. "How many questions do you have?" "It depends on how you answer them", Botha replied' (Mamtse, 2007).

- 'His questions make us [directors] look silly' (Keeping tycoons on their toes, 2007).

- 'Chairmen hate him [for exposing them]. He has been threatened, ranted at, patronised, called an idiot and thrown out of meetings. Some of his victims have suggested that Botha is just an egomaniac who loves being in the newspapers' (Barron, 2008).

- The director's response was 'aggressive, dismissive and abrupt' (Barron, 2008).

- Botha is seen as a 'nuisance' (Ngcobo, 2011).

- 'Most company chairmen don't like seeing Theo Botha turning up at their AGMs' (Hogg, 2011).

- 'One could feel the tension in the room following Botha's barrage of questions. It was as if we were on a knife-edge' (Vanek, 2012c).

- 'AGMs in South Africa are usually dull affairs. That's apart from the cold sweat directors break out into if they see Botha walking through the door armed with his list of difficult questions' (Williams, 2013).

- Botha ensured the meeting 'was not without a little frisson' (Crotty, 2014).

From the above it can be deduced that many chairpersons and directors in South Africa are uncomfortable with Botha's actions and that many do not perceive Botha as a credible shareholder activist. Botha himself acknowledges that boards see him as an 'irritation' (TB in Steyn, 2011). Even so, he continues to engage them year after year. Social commentators, however, recognise the key role that Botha has played in bringing about corporate change. 
Tredway (2004), for example, asserts that Botha's presence at an AGM ensures that 'directors are asked the sort of questions that other shareholders should be asking were they not apathetic or embedded'.

Another journalist affirms that Botha is not a typical activist. 'He doesn't carry placards or wear T-shirts with socialist slogans. He is always mild-mannered, well-spoken and neatly dressed' (Keeping tycoons on their toes, 2007). Steyn (2011) also contends that it is hard to judge from Botha's business-like appearance and demeanour, that he can be a 'pesky thorn in the side of many large corporations'.

Shareholder activists can develop pragmatic legitimacy in two ways: firstly, by presenting a convincing argument for why their actions are in the best interest of the company and secondly by providing the company with new information (Gifford, 2010). Botha has a sound track record in both of these areas. Many of the issues highlighted by Botha could, if left unattended, result in adverse financial implications for the company in question. Poor environmental practices could, for example, lead to litigation and costly fines. Against this background, Mpofu (2013) was not incorrect in asserting that Botha is 'that shareholder any business executive ought to listen to'.

Botha's public criticism of companies has been shown to have an immediate and significant negative impact on their share prices (Bhana, 2010). This finding implies that Botha's criticism contains valuable information for both management and the rest of the market. However, one author observed 'a weariness' in Botha's voice when Botha referred to the 'free advice' he gives JSE-listed companies with little appreciation, except from the media (Keeping tycoons on their toes, 2007).

Social legitimacy depends on the extent to which a shareholder embodies or reflects a position widely accepted in society (Gifford, 2010). Within the South African context, Botha has been quite vocal about issues that are central to the creation of a just society. These include the lack of transformation (especially at board level), HIV/AIDS-related issues, and the ever-increasing wage gap (Barron, 2008, 2014; Gilmour, 2014; Sathekge, 2011; Tarrant, 2013). More recently, he has also engaged with companies on sustainability concerns and the impact that poor environmental practices have on local communities (Crotty, 2013; Salgado, 2008).

Social legitimacy also stems from the existence of norms and codes of conduct as well as a supportive political and policy environment. Although South Africa has been a pioneer in the development and implementation of good corporate governance codes by means of the King I, II and III reports, Botha is very sceptical of the effectiveness of these codes (Carte, 2009; Crotty, 2009a). As a veteran shareholder activist (Barron, 2014), Botha was invited to serve as independent committee member of the team that designed the Code for Responsible Investing in South Africa (Institute of Directors Southern Africa, 2014). This code provides guidance to institutional investors in adhering to the amended Regulation 28 and King III's recommendations.

\subsection{Does urgency play a role in making Botha a salient individual shareholder activist?}

The third attribute of shareholder salience is that of urgency. Urgency, in turn, depends on the time-sensitivity and criticality of the relationship between the shareholder and management. Given the nature of this study, only criticality was deemed relevant. Criticality can be gauged in terms of behaviour that illustrates a resolve or determination to address issues of concern (Gifford, 2010). 
Criticality is associated with assertiveness of tone, persistence and the willingness to apply resources. Assertiveness of tone implies that the shareholder should be unafraid of asking difficult questions. Botha is most definitely an assertive shareholder activist. He has often been described as being outspoken, vocal, challenging, demanding and adamant (Ashton, 2008; Hasenfuss, 2008, 2009c; Rose, 2007a; Slabbert, 2013). Stated differently, Botha 'doesn't mince his words about the lack of good corporate governance' (Mantshantsha, 2009).

Botha's insistence on answers and official recordkeeping is well noted. More than one South African director has 'been pressed' for explanations (Monteiro, 2009; Vanek, 2012b) or has been subjected to 'stinging criticism' from Botha (Cynthia Carroll takes over as Anglo Platinum chairperson, 2010). An assertive or confrontational activism style (such as that exhibited by Botha) has proved to be more successful than a less aggressive style (Klein \& Zur, 2009).

Criticality is also measured in terms of persistence. This source of salience has been the hallmark of many leading activists, most notably Mahatma Ghandi and Nelson Mandela. Persistence is particularly important in the face of (apparent) failure and might explain why Botha often returns to the same companies year after year. In more than a third of cases, Botha attended the AGMs of the same company for three consecutive years. Botha admits that he is tenacious in pursuing his objectives (TB). Further evidence of Botha's persistence can be gleaned from newspaper reports in which he is described as 'relentless' and 'bloody-minded' (Barron, 2008; Shevel, 2014; Steyn, 2011). Mpofu (2013) succinctly captures Botha's determination in the following quote: 'Botha's relentless push to put his money where his mouth is has on several occasions led him on a collision course with various boards.'

Despite being a 'lone voice' (Harris, 2011b; Vanek, 2012d), Botha has persisted in engaging JSElisted companies on issues they 'would rather have kept to themselves' (Barron, 2008). He admits that it has been a constant, uphill struggle, but that he is slowly starting to see improved governance among JSE-listed companies (TB in Steyn, 2011). Botha's claim concurs with De Bakker and Den Hond (2008), who found that the presence of shareholder activists at AGMs (albeit individual activists) has led to changes in corporate policies. They attributed these changes to target companies' fear of reputational damage.

The final measure of criticality relates to a shareholder's willingness to apply resources. Botha has always used his own finances to prepare for and attend AGMs throughout South Africa (TB; Mamste, 2007; Petros, 2009). He has also travelled to London at his own expense, to attend a number of AGMs of dual-listed companies (Crotty, 2011b, 2013; Rose \& Shevel, 2009; Steyn, 2011). Botha has been quite critical of dual-listed companies that do not provide their South African shareholders with video or telephonic links to their AGM in London (Hasenfuss, 2009a).

\section{SUMMARY AND CONCLUSIONS}

To address the lack of academic research on individual shareholder activism, this article set out to identify the motives, modus operandi and sources of salience of a prominent individual shareholder activist. The document analysis and in-depth interview with Botha revealed that he not only has a clear goal, namely to keep managers and directors accountable, but is also very passionate about achieving this goal. He prepares meticulously before engaging companies, which strengthens perceptions regarding his individual legitimacy.

According to Bhana (2010), Botha also has an 'impressive ability' to anticipate the effects of corporate decisions on operating profitability. Although Botha is widely regarded as a corporate 
governance expert, he has also questioned companies on a range of other socially relevant issues, thereby enhancing his level of social legitimacy. The scope of Botha's questions, and the fact that he does not benefit financially from his engagements, reflects both a utilitarian and a deontological ethical orientation. The former is evident from his efforts to promote transformation in businesses, whereas the latter is reflected in his concerns about adherence to corporate governance codes.

As an experienced shareholder activist, Botha knows how to use the media to his advantage, which gives him substantial normative power. He has also gained invaluable experience over the years by engaging companies across the economic spectrum. Botha is an assertive and persistent activist who is willing to apply his own resources to engage companies. Although tenacious, Botha is still regarded as being mild-mannered and polite (Keeping tycoons on their toes, 2007; Mamtse, 2007). He is not afraid to speak his mind and has often used humour to defuse potentially tense situations (Barron, 2008).

The findings of this study suggest that Botha has a strong internal locus of control and is thus likely to continue with his efforts to improve corporate policies and practices in South Africa. However, he admits that he is tired of being the only one who seems to be concerned about good governance and would like more South African investors, big or small, engaging local companies (TB; Hogg, 2010; Shevel, 2014). In an attempt to encourage other investors to vote at AGMs, Botha has recently started to publish his proxy opinions online (Barry, 2014b). Finally, Botha would like to see King III being simplified to encourage greater compliance among South African companies (Planting, 2012).

The findings of this study suggest that shareholder salience, especially in the case of an individual shareholder, calls for passion, strength of conviction, the ability to use the media to one's advantage and the cultivation of individual, pragmatic and societal legitimacy. Even more important is the resolve to persevere in one's attempts to bring about greater corporate accountability and transparency, despite real or perceived resistance.

\section{LIST OF REFERENCES}

Anderson, B. (2006a). Tiger Brands looks to ARV's. Fin24, 23 February. Available: http://www.fin24.com/Companies/Tiger-Brands-looks-to-ARVs-20060223 (Accessed 1 April 2013).

Anderson, B. (2006b). Nampak's governance grilling. Fin24, 8 August. Available: http://www.fin24.com/Companies/Nampaks-governance-grilling-20060208 (Accessed l April 2013).

Ashton, M. (2008). Bidvest fields tough questions. Fin24, 17 November. Available: http://www.fin24.com/Companies/Bidvest-fields-tough-questions-20081117 (Accessed 4 May 2014).

Babbie, E. \& Mouton, J. (2001). The practice of social research. South African edition. Cape Town: Oxford University Press.

Barron, C. (2008). Chairmen often can't stand the sight of him. Financial Mail, 20 July. Available: http://www.netassets.co.za/article.aspx?id=80597 (Accessed 5 0ctober 2013).

Barron, C. (2011). Roy McAlpine: A legend is getting off the bus. Times Live, 29 May. Available: http://www.timeslive.co.za/business/2011/05/29/newsmaker-roy-mcalpine-a-legend-is-gettingoff-the-bus (Accessed 50 ctober 2013). 
Barron, C. (2014). Something's got to give on CE0 pay. Sunday Times Business Times, 18 May. Available: http://www.bdlive.co.za/companies/2014/05/18/something-s-got-to-give-on-ceo-pay (Accessed 18 May 2014).

Barry, H. (2014a). Fix management, fix Abil. Moneyweb, 5 May. Available: http://www.moneyweb.co.za/moneyweb-financial/fix-management-fix-abil (Accessed 5 May 2014).

Barry, H. (2014b). Shareholder activist sells views to public. Moneyweb, 1 April. Available: http://www.moneyweb.co.za/moneyweb-corporate-governance/shareholder-activist-sells-viewsto-public (Accessed l April 2014).

Becht, M., Franks, J., Mayer, C. \& Rossi, S. (2010). Returns to shareholder activism: evidence from a clinical study of the Hermes UK Focus Fund. The Review of Financial Studies, 23(3), pp. 3093-3129.

Bhana, N. (2010). The stock market reaction to criticism of corporate governance practices of companies listed on the JSE. Investment Analysts Journal, 72, pp. 1-12.

Blume, M.E. \& Keim, D.B. (2012). Institutional investors and stock market liquidity: trends and relationships. Socia/ Science Research Network, 21 August. Available:

http://ssrn.com/abstract=2147757 (Accessed 6 October 2013).

CA Governance. (2014). Available: http://www.ca-governance.co.za/index.php/our-team.html (Accessed 20 January 2014).

Carte, D. (2009). King 3's too soft. Moneyweb, 19 May. Available:

http://www.moneyweb.co.za/moneyweb-corporate-governance/king-3s-too-soft (Accessed 25 September 2013).

Carte, D. (2011). Barloworld bosses grilled at AGM. Moneyweb, 26 January. Available:

http://www.moneyweb.co.za/moneyweb-industrials/barloworld-bosses-grilled-at-agm (Accessed 5 October 2013).

Chung, H. \& Talaulicar, T. (2010). Forms and effects of shareholder activism. Corporate Governance: An International Review, 18(4), pp. 253-257.

Cohen, T. (2011). The BદE deal that should never have been. Business Day, 28 September, p. 16.

Creamer, M. (2009). Sacked Wesizwe CE0 scrapes back in pyrrhic victory. Mining Weekly, 17 December. Available: http://www.miningweekly.com/article/sacked-wesizwe-ceo-scrapes-back-in-pyhrricvictory-2009-12-17 (Accessed 4 October 2013).

Crotty, A. (2009a). Governance by directors, for directors. The Star, 20 April, p. 18.

Crotty, A. (2009b). Absa 'was not asked to assist Barclays last year'. The Star, 23 April, p. 3.

Crotty, A. (2011a). Botha grills Nampak for chief's share allocation. Business Report, 14 March. Available: http://www.iol.co.za/business/companies/botha-grills-nampak-for-chief-s-shareallocation-1.1041427 (Accessed 3 October 2013).

Crotty, A. (2011b). Anglo gives activist Botha the boot. Business Report, 26 April. Available: http://www.iol.co.za/business/companies/anglo-gives-activist-botha-the-boot-1.1061125 (Accessed 3 October 2013).

Crotty, A. (2012a). Shareholder activist turns up the heat on Barloworld boss's bonus. Business Report, 26 January. Available: http://www.iol.co.za/business/business-news/shareholder-activistturns-up-the-heat-on-barloworld-boss-s-bonus-1.1220474 (Accessed 50 0ctober 2013). 
Crotty, A. (2012b). Lonmin nudged into minute silence for Marikana. 10L, 20 November. Available: http://www.iol.co.za/business/news/lonmin-nudged-into-minute-silence-for-marikana-1.1426615 (Accessed 7 June 2013).

Crotty, A. (2013). Anglo's bonuses called into question. Business Report, 2 August. Available: http://www.iol.co.za/business/news/anglo-s-bonuses-called-into-question-1.1556497 (Accessed 2 August 2013).

Crotty, A. (2014). Microlender thrives in debt storm. Sunday Times Business Times, 1 June. Available: http://www.bdlive.co.za/businesstimes/2014/06/01/microlender-thrives-in-debt-storm (Accessed 1 June 2014).

Cynthia Carroll takes over as Anglo Platinum chairperson. (2010). Mineweb, 6 July. Available: http://www.miningreview.com/cynthia-carroll-takes-over-as-anglo-platinum-chairperson/ (Accessed 4 February 2014).

Davis, G.F. \& Han Kim, દ. (2007). Business ties and proxy voting by mutual funds. Journal of Financial Economics, 85(2), pp. 552-570.

De Bakker, F.G.A. \& Den Hond, F. (2008). Activists' influence tactics and corporate policies. Business Communication Quarterly, 71 (1), pp. 107-111.

De Waal, M. (2011). High drama at Avusa amid rumours of Prakash Desai's departure. Daily Maverick, 21 September. Available: http://www.dailymaverick.co.za/article/2011-09-21-high-drama-atavusa-amid-rumours-of-prakash-desais-departure (Accessed 31 July 2013).

Elo, S. \& Kyngäs, H. (2007). The qualitative content analysis process. Journal of Advanced Nursing, 62(1), pp. 107-115.

Flam, H. \& King, D. (Eds.) (2007). Emotions and social movements. London: Routledge.

Foley, S. (2014). Carl Icahn, obsessive activist investor. Financial Times, 21 February. Available: http://www.ft.com/cms/s/0/d4d05c84-9a54-1le3-8232-00144feab7de.htm|" axzz33eU5AFB8 (Accessed 21 February 2014).

Gantchev, N. (2013). The costs of shareholder activism: Evidence from a sequential decision model. Journal of Financial Economics, 107(3), pp. 610-631.

Gardee, R. (2014). BEદ shareholder activism set to rise. Moneyweb, 5 March. Available:

http://www.moneyweb.co.za/moneyweb-soapbox/bee-shareholder-activism-set-to-rise (Accessed 5 March 2014).

Gifford, J.E. (2010). Effective shareholder engagement: The factors that contribute to shareholder salience. Journal of Business Ethics, 92(1), pp. 79-97.

Gillan, S.L. \& Starks, L.T. (2000). Corporate governance proposals and shareholder activism: The role of institutional investors. Journal of Financial Economics, 57(2), pp. 275-305.

Gilmour, J. (2014). No-show Peter Matlare gets reappointed to Barclays Africa. Moneyweb, 6 May. Available: http://www.moneyweb.co.za/moneyweb-financial/noshow-peter-matlare-getsreappointed-to-barclays- (Accessed 6 May 2014).

Hadani, M., Goranova, M. \& Khan, R. (2011). Institutional investors, shareholder activism and earnings management. Journal of Business Research, 64(12), pp. 1352-1360.

Harris, S. (2011a). A bazaar of errors. Finweek, 5 December, p. 1. 
Harris, S. (2011b). Pulp fiction. Fin24, 21 April. Available: http://www.fin24.com/Finweek/CoverStory/Pulp-fiction-20110418 (Accessed 21 February 2014).

Harris, S. (2014). Sappi's results belie the hill it has to climb. Business Day, 19 May. Available: http://www.bdlive.co.za/business/industrials/2014/05/19/sappis-results-belie-the-hill-it-hasto-climb (Accessed 19 May 2014).

Hasenfuss, M. (2006). Who is Theo Botha? Finweek, 13 July, p. 12.

Hasenfuss, M. (2007). Journos banned again. Fin24, 15 February. Available:

http://www.fin24.com/Companies/Journos-banned-again-20070215 (Accessed 21 May 2013).

Hasenfuss, M. (2008). No related party issues at Remgro. Finweek, 30 0ctober, pp. 24-25.

Hasenfuss, M. (2009a). No links to London. Finweek, 21 May, p. 30.

Hasenfuss, M. (2009b). Board blasted for doing 'nothing'. Fin24, 26 November. Available:

http://www.fin24.com/Companies/Board-blasted-for-doing-nothing-20091126

(Accessed 4 February 2014).

Hasenfuss, M. (2009c). Brand damage. Fin24, 27 November. Available:

http://www.fin24.com/Opinion/Columnists/Marc-Hasenfuss/Brand-damage-20091127

(Accessed 4 February 2014).

Hasenfuss, M. (2010). Say hello to Halco. Finweek, 20 May, p. 34.

Hedley, N. (2013). Call for improved disclosure of executive bonuses. Business News, 21 November. Available: http://businessnews.howzit.msn.com/call-for-improved-disclosure-of-executivebonuses (Accessed 21 November 2013).

Hendry, J., Sanderson, P., Barker, R. \& Roberts, J. (2007). Responsible ownership, shareholder value and the new shareholder activism. Competition \& Change, 11(3), pp. 223-240.

Hogg, A. (2008). Gold Reef's proposed share incentive scheme amended. Theo Botha - shareholder activist. Moneyweb, 19 August. Available: http://www.moneyweb.co.za/moneyweb-safm-marketupdate/gold-reefs-proposed-share-incentive-scheme-amended?sn=2009+Detail (Accessed 25 January 2014).

Hogg, A. (2009). AGMs, shareholder activism, remuneration committees, directors: Theo Botha shareholder activist. Moneyweb, 20 ctober. Available: http://www.moneyweb.co.za/moneywebsafm-market-update/agms-shareholder-activism-remuneration-committees- (Accessed 8 February 2014).

Hogg, A. (2010). Sasol executive remuneration: Theo Botha - shareholder activist. Moneyweb, 30 November. Available: http://www.moneyweb.co.za/moneyweb-safm-market-update/sasolexecutive-remuneration-theo-botha--shareholdhttp://www.moneyweb.co.za/moneyweb-safmmarket-update/sasol-executive-remuneration-theo-botha--sharehold (Accessed 8 February 2014).

Hogg, A. (2011). New Sasol CE0's pay - Theo Botha (shareholder activist); and Hyprop placement exceeds expectations - Dale Wood (RMB). Moneyweb, 25 November. Available: http://www.moneyweb.co.za/moneyweb-safm-market-update/new-sasol-ceos-pay--theo-bothashareholder-activis (Accessed 8 February 2014).

Institute of Directors Southern Africa. (2014). Members of the CRISA committee. Available: http://www.iod.wowinteractive3.co.za/PRODUCTSSERVICES/CodeforResponsiblelnvestinginSACRISA/ MembersoftheCRISACommittee.aspx (Accessed 8 January 2014). 
Jones, G. (2014). ABIL: Too soon to panic. Financia/ Mail, 22 May. Available:

http://www.financialmail.co.za/features/2014/05/22/abil-too-soon-to-panic (Accessed 22 May 2014).

Judge, W.Q., Guar, A. \& Muller-Kahle, M.I. (2010). Antecedents of shareholder activism in target firms: evidence from a multi-country study. Corporate Governance: An International Review, 18(4), pp. 258273.

Keeping tycoons on their toes. (2007). Mail \& Guardian, 10 May. Available: http://www.mg.co.za/article/2007-05-10-keeping-tycoons-on-their-toes (Accessed 20 July 2013).

Klein, A. \& Zur, E. (2009). Entrepreneurial shareholder activism: hedge funds and other private investors. The Journal of Finance, 64(1), pp. 187-229.

Lantz, J-S., Montandrau, S. \& Sahut, J-M. (2010). Activism of institutional investors, corporate alerts and financial performance. International Journal of Business, 15(2), pp. 221-240.

Lekhesa, M.W. (2009). Shareholder activism: the birth of a new phenomenon in South African corporate law. Unpublished Masters Dissertation. Bloemfontein: University of the Free State.

Mamtse, D. (2007). Theo Botha - shareholder activist, troublemaker. Moneyweb, 5 February. Available: http://www.moneyweb.co.za/moneyweb-ict/theo-botha--shareholder-activisttroublemaker (Accessed 5 March 2014).

Mantshantsha, S. (2006). Dorbyl chiefs jump ship. Fin24, 25 August. Available: http://www.fin24.com/Companies/Dorbyl-chiefs-jump-ship-20060825 (Accessed 5 March 2014).

Mantshantsha, S. (2007). Astral found wanting on BEદ. Fin24, 15 February. Available: http://www.fin24.com/Companies/Astral-found-wanting-on-BEE-20070215 (Accessed 5 March 2014).

Mantshantsha, S. (2009). The face of disaster. Fin24, 19 November. Available: http://www.fin24.com/Finweek/Insight/The-face-of-disaster-20091114-2 (Accessed 5 March 2014). Mathews, C. \& Hasenfuss, M. (2013). Money talks. Financial Mail, 23 May. Available: http://www.fm.co.za/business/money/2013/05/23/money-talks [Accessed 23 May 2013].

Mchunu, S. (2007b). All not well at Metrofile. Fin24, 3 December. Available: http://www.fin24.com/Companies/All-not-well-at-Metrofile-20071203 (Accessed 6 June 2013).

Mpofu, B. (2013). Minority shareholders bear burden of corporate politics: Part 1. Newsday, 28 March. Available: http://www.newsday.co.zw/2013/03/28/minority-shareholders-bear/ (Accessed 28 March 2013).

Mitton, T. (2002). A cross-firm analysis of the impact of corporate governance on the East-Asian financial crisis. Journal of Financial Economics, 64(2), pp. 215-241.

Monteiro, J. (2009). Outcry over Sappi CE0’s bonus. Fin24, 2 March. Available:

http://www.fin24.com/Companies/Outcry-over-Sappi-CEOs-bonus-20090302 (Accessed 8 June 2013).

Ngcobo, S. (2011). Anglo's AGM, Theo Botha and conspiracy theories. Moneyweb, 18 May. Available: http://www.moneyweb.co.za/moneyweb-the-perfect-storm/anglos-agm-theo-botha-andconspiracy-theories (Accessed 6 June 2013).

Nordén, L. \& Strand, T. (2011). Shareholder activism among portfolio managers: rational decision or 15 minutes of fame? Journal of Management Governance, 15(3), pp. 375-391. 
Ntim, C.G., Opong, K.K. \& Danbolt, J. (2012). The relative value relevance of shareholder versus stakeholder corporate governance disclosure policy reforms in South Africa. Corporate Governance: An International Review, 20(1), pp. 84-105.

Our mission and values. (2016). Lonmin. Available: https://www.lonmin.com/about-us/missionand-values (Accessed 2 December 2015).

Partnoy, F. \& Thomas, R. (2005). The new shareholder activism. Social Sciences Research Network. Available: http://ssrn.com/abstract=876344 (Accessed 6 June 2013).

Patton, C. (2014). Amplats chair 'not deaf' to executive pay furore. Business Day, 19 May. Available: http://www.bdlive.co.za/business/mining/2014/05/19/amplats-chair-not-deaf-to-executive-payfurore (Accessed 19 May 2014).

Petros, N. (2009). Botha has his say, but Remgro gets to unwrite story. The Star, 18 August, p. 2.

Planting, S. (2012). We need more capitalist activists - Theo Botha, Moneyweb, 29 February.

Available: http://www.moneyweb.co.za/moneyweb-corporate-governance/we-need-morecapitalist-activists--theo-botha (Accessed 5 June 2013).

Planting, S. (2014). Shareholder told politely to go jump. Moneyweb, 1 April. Available: http://www.moneyweb.co.za/moneyweb-industrials/shareholder-told-politely-to-go-jump (Accessed l April 2014).

Poulsen, T., Strand, T. \& Thomsen, S. (2010). Voting power and shareholder activism: a study of Swedish shareholder meetings. Corporate Governance: An International Review, 18(4), pp. 329-343.

Rademeyer, C. \& Holtzhausen, J. (2004). King II, corporate governance and shareholder activism. South African Law Journal, 120(4), pp. 767-775.

Radebe, S. (2008). BEE debate rages on. Financia/ Mail, 15 August. Available: http://archive.is/BGhvs (Accessed 6 June 2013).

Rose, R. (2005). Momentum gets nod to buy Sage. Business Day, 17 August. Available: http://allafrica.com/stories/200508170121.htm/(Accessed 7 June 2013).

Rose, R. (2007a). Liberty grilled over directors' bonuses, poor performance. Business Day, 25 May. Available: http://allafrica.com/stories/200705250115.html (Accessed 6 June 2013).

Rose, R. (2007b). Bashful activist raises hackles of corporate SA. Business Day, 9 February. Available: http://allafrica.com/stories/200702090818.html (Accessed 6 June 2013).

Rose, R. \& Shevel, A. (2009). SABMiller loses its cheer for PIC's Molefe, Sunday Times Business Times, p. 1.

Salgado, I. (2008). PPC: clean air versus profit is a dilemma. The Star, 11 February, p. 21.

Sathekge, B. (2011). Retailers 'shirking' Bદદ. The New Age, 21 November. Available: http://www.thenewage.co.za/Detail.aspx?news_id $=35629 \&$ cat_id=9\&mid=53 (Accessed 21 January 2014).

Schumacher, I. (2009). Anglo Plats minorities angry. Miningm ${ }^{x}, 30$ March. Available: http://www.miningmx.com/news/platinum_group_metals/979815.htm (Accessed 12 April 2014).

Seccombe, A. (2012). Lonmin investors give $\$ 817 \mathrm{~m}$ share issue the nod. Business Day, 20 November. Available: http://www.bdlive.co.za/business/mining/2012/11/20/lonmin-investors-give-817mshare-issue-the-nod (Accessed 10 June 2013). 
Viviers

Sexwale and the shy corporate activist. (2007). Business Day, 3 May. Available: http://www.mobilitytechzone.com/news/2007/05/03/2581381.htm (Accessed 5 June 2013).

Shevel, A. (2014). Terrier-like Botha keeps companies on a leash. Sunday Times Business Times, 2 February. Available: http://www.bdlive.co.za/business/2014/02/02/terrier-like-botha-keepscompanies-on-a-leash (Accessed 2 February 2014).

Sjöstrom, દ. (2008). Shareholder activism for corporate social responsibility. Sustainable Development, 16(3), pp. 141-154.

Slabbert, A. (2013). Times Media Group under fire for lack of disclosure. Moneyweb, 4 December. Available: http://www.moneyweb.co.za/moneyweb-corporate-governance/times-media-groupunder-fire-for-lack-of-disclosur (Accessed 4 May 2013).

Steyn, L. (2011). Theo Botha -- the shareholder activist. Mail \& Guardian, 13 May. Available: http://mg.co.za/article/2011-05-13-theo-botha-the-shareholder-activist (Accessed 20 July 2013).

Tarrant, H. (2013). Valli Moosa replaces Cynthia Carroll as Angloplat chair: Theo Botha - activist. Moneyweb, 26 April. Available: http://www.moneyweb.co.za/moneyweb-safm-market-update/r1064 (Accessed 26 April 2013).

Tarrant, H. (2014). Questions, concerns surround Steinhoff's offer for JD Group: Theo Botha shareholder activist. Moneyweb, 19 March. Available: http://www.moneyweb.co.za/moneyweb-safmmarket-update/questions-concerns-surround-steinhoffs-offer-for- (Accessed 19 March 2014).

Tredway, G. (2004). Aflease activist attacked. Mineweb, 23 September. Available:

http://www.mineweb.com/mineweb/content/en/mineweb-historical-dailynews? oid $=13495 \&$ sn=Daily+news+Detail (Accessed 1 July 2013).

Vanek, M. (2012a). Shareholder activism blocks Bidvest resolution. Moneyweb, 28 November. Available: http://www.moneyweb.co.za/moneyweb-corporate-governance/shareholder-activismblocks-bidvest-resolution (Accessed 2 July 2013).

Vanek, M. (2012b). Tiger top execs accused of sitting on too many boards. Moneyweb, 14 February. Available: http://www.moneyweb.co.za/moneyweb-industrials/tiger-top-execs-accused-ofsitting-on-too-many-boa (Accessed 2 July 2013).

Vanek, M. (2012c). Investec, PIC did not act in concert on JD/KAP deal. Moneyweb, 12 March. Available: http://www.moneyweb.co.za/moneyweb-industrials/investec-pic-did-not-act-inconcert-on-jdkap-deal (Accessed 2 July 2013).

Vanek, M. (2012d). Bonus bothers Botha. The Citizen, 4 May. Available: http://www.citizen.co.za/citizen/content/en/citizen/businessnews?oid=276095\&sn=Detail\&pid=146848\&Bonus-bothers-Botha (Accessed 2 July 2013).

Viviers, S. \& Smit, $\varepsilon$. van der M. 2015. Institutional proxy voting in South Africa: process, outcomes and impact. South African Journal of Business Management, 46(3), pp. 23-34.

Welker, M. \& Wood, D. (2011). Shareholder activism and alienation. Current Anthropology, 52(S3), pp. S57-S69

Wen, S. (2009). Institutional investor activism on socially responsible investment: effect and expectations. Business Ethics: A European Review, 18(3), pp. 308-333.

Williams, F. (2013). As dull as an ... AGM. City Press, 2 December. Available:

http://www.citypress.co.za/business/dull-an\%E2\%80\%89-agm/ (Accessed 2 December 2013). 
Winfield, J. (2011). The landscape of proxy voting at South African asset managers. RisCura. July. Available: http://www.riscura.com/docs/research/SpoiltVotesHigh_Aug2011.pdf (Accessed 8 June 2013). 